\title{
Pendokumentasian Proses Asuhan Keperawatan
}

\author{
Adisty Olyvia Hutagalung
}

\section{Adistyhutagalung@gmail.com}

\section{Latar Belakang}

Rumah sakit sebagai salah satu sarana pelayanan kesehatan yang melakukan pelayanan rawat jalan maupun rawat inap wajib untuk membuat rekam medis. Penanggung jawab pengisian rekam medis adalah Dokter umum, dokter spesialis, dokter gigi dan dokter spesialis yang melayani pasien di rumah sakit, dokter tamu, residen, perawat, perawat gigi, bidan, tenaga laboratorium klinik, gizi, anestesi, penata rontgen, rehabilitasi medik (Depkes RI, 2006).

Peran perawat sebagai salah satu tenaga kesehatan mempunyai kontribusi besar bagi pelayanan kesehatan dalam upaya peningkatan mutu pelayanan kesehatan. Profesi keperawatan saat ini merupakan profesi yang memiliki resiko hukum, kesalahan perawatan yang mengakibatkan kecacatan atau kematian bagi pasien dapat menyeret perawat ke pengadilan, karenanya segala aktifitas yang dilakukan terhadap pasien harus di dokumentasikan dengan baik dan jelas.

Pendokumentasian yang efektif dan efisien dapat meningkatkan mutu pelayanan keperawatan yang dirasakan oleh klien. Pendokumentasian asuhan keperawatan wajib lengkap dan sesuai standar karena merupakan penghubung untuk mengetahui perkembangan kesehatan pasien, oleh karena itu melengkapi dokumentasi asuhan keperawatan adalah kewajiban seorang perawat.

Sebagaimana diatur dalam Permenkes RI Nomor. HK.02.02/Menkes/148/ I/2010 tentang izin dan penyelenggaraan praktik keperawatan dan ditetapkan dalam SK Menkes No.436/ Menkes/SK/VI/1993 tentang standar pelayanan rumah sakit.

Dokumentasi keperawatan adalah setiap catatan baik tertulis maupun elektronik yang menggambarkan layanan keperawatan yang diberikan kepada klien dan dapat digunakan sebagai bukti bagi tenaga yang berwenang.

Penyelenggaraan proses keperawatan terdiri dari pengkajian, diagnosa, perencanaan, implementasi dan evaluasi. Semua tindakan tersebut harus didokumentasikan sebagai bukti penyelenggaraan proses keperawatan. Oleh karena itu, dilakukan penelitian mengenai pendokumentasian berdasarkan proses keperawatan. 


\section{Metode}

Metode yang digunakan adalah literature review. Kajian literature meninjau literatur ilmiah tentang sebuah topik dan secara kritis menganalisis, mengevaluasi, dan menyintesis temuan penelitian, teori, dan praktik. Pencarian artikel penelitian menggunakan jurnal, tesis, skripsi, disertasi, artikel dan lainnya dengan menggunakan kata kunci yaitu dokumentasi keperawatan, asuhan keperawatan, proses keperawatan, pendokumentasian. Kriteria inklusi yaitu artikel full text yang berbahasa Inggris atau berbahasa Indonesia dipublikasikan dengan tahun paling lama 2012. Jumlah keseluruhan artikel yang didapatkan dilakukan penyaringan sesuai dengan kriteria inklusi sehingga hasil akhir ditemukan 10 artikel yang di review.

\section{Hasil}

Dalam Modul Bahan Ajar Cetak Keperawatan : Dokumentasi Keperawatan (2016), proses keperawatan adalah metode pemberian asuhan keperawatan yang dilakukan secara sistematis, teratur dan berkelanjutan untuk membantu klien/pasien mengatasi masalah keperawatan yang dihadapinya melalui serangkaian intervensi berdasarkan ilmu dan kiat keperawatan. Proses tersebut meliputi pengkajian, diagnosa keperawatan, perencanaan, tindakan dan evaluasi.

1. Pengkajian

Dokumentasi pengkajian merupakan catatan tentang hasil pengkajian yang dilaksanakan untuk mengumpulkan informasi dari pasien, membuat data dasar tentang klien, dan membuat catatan tentang respons kesehatan klien. Tahap ini merupakan dasar dalam mengidentifikasi kebutuhan keperawatan klien. Pengkajian yang akurat, sistematis dan kontinu akan membantu menentukan tahapan selanjutnya dalam proses keperawatan.

2. Diagnosa

Diagnosa keperawatan merupakan tahap selanjutnya pada proses keperawatan yang dilakukan setelah pengkajian. Diagnosa keperawatan merupakan dasar dalam penyusunan rencana tindakan asuhan keperawatan. Dokumentasi diagnosa keperawatan perlu diperhatikan karena diagnosa keperawatan merupakan dasar dalam penyusunan perencanaan keperawatan, oleh karena itu diagnosa keperawatan ini harus terdokumentasi dengan baik.

3. Perencanaan

Perencanaan merupakan pengembangan dari strategi untuk mencegah, mengurangi atau mengoreksi masalah-masalah yang diidentifikasi pada diagnosa 
keperawatan. Pada tahap ini perawat membuat rencana tindakan keperawatan untuk mengatasi masalah dan meningkatkan kesehatan pasien.

4. Implementasi

Implementasi keperawatan adalah serangkaian kegiatan yang dilakukan oleh perawat untuk membantu klien dari masalah status kesehatan yang dihadapi kestatus kesehatan yang baik yang menggambarkan kriteria hasil yang diharapkan.

5. Evaluasi

Evaluasi keperawatan merupakan tahap akhir dari rangkaian proses keperawatan yang berguna apakah tujuan dari tindakan keperawatan yang telah dilakukan tercapai atau perlu pendekatan lain. Evaluasi keperawatan adalah mengukur keberhasilan dari rencana dan pelaksanaan tindakan keperawatan yang dilakukan dalam memenuhi kebutuhan klien. Penilaian adalah tahap yang menentukan apakah tujuan tercapai. Evaluasi selalu berkaitan dengan tujuan.

\section{Pembahasan}

Dari hasil didapatkan bahwa pendokumentasian proses asuhan keperawatan sangat penting. Asuhan Keperawatan adalah rangkaian interaksi Perawat dengan Klien dan lingkungannya untuk mencapai tujuan pemenuhan kebutuhan dan kemandirian Klien dalam merawat dirinya Proses tersebut meliputi pengkajian, diagnosa keperawatan, perencanaan, tindakan dan evaluasi. Dokumentasi salah satu catatan otentik dalam penerapan managemen asuhan keperawatan professional. Perawat professional diharapkan dapat menghadapi tuntutan tanggung jawab dan gugat terhadap segala tindakan yang dilakukan.

1. Pengkajian

Dokumentasi pengkajian merupakan catatan tentang hasil pengkajian yang dilaksanakan untuk mengumpulkan informasi dari pasien, membuat data dasar tentang klien, dan membuat catatan tentang respons kesehatan klien. Dengan demikian hasil pengkajian sangat mendukung untuk mengidentifikasi masalah kesehatan klien dengan baik dan tepat. Dalam melaksanakan dokumentasi pada fase pengkajian perlu kita ketahui dahulu tentang jenis dokumentasi pengkajian yang meliputi:

a. Dokumentasi pada saat pengkajian awal atau dikenal dengan Initialassessment. Dokumentasi yang dibuat manakala pasien pertama kali masuk rumah sakit. Data yang dikaji pada pasien berupa data awal yang digunakan sebagai dasar dalam pemberian asuhan keperawatan. 
b. Dokumentasi pengkajian lanjutan atau Ongoing assessment. Data pada pendokumentasian ini merupakan pengembangan data dasar, yang dilakukan untuk melengkapi pengkajian awal agar semua data menjadi lengkap sehingga mendukung informasi tentang permasalahan kesehatan pasien. Hasil pengkajian pada dokumentasi ini di masukkan dalam catatan perkembangan pasien atau pada lembar data penunjang.

c. Dokumentasi pengkajian ulang (reassesment) merupakan pencatatan terhadap hasil pengkajian yang didapat dari informasi selama evaluasi. Dalam hal ini perawat mengevaluasi kemajuan data terhadap masalah klien yang sudah ditemukan.

2. Diagnosa

Diagnosa keperawatan merupakan tahap selanjutnya pada proses keperawatan yang dilakukan setelah pengkajian. Diagnosa keperawatan merupakan dasar dalam penyusunan rencana tindakan asuhan keperawatan. Dokumentasi diagnosa keperawatan perlu diperhatikan karena diagnosa keperawatan merupakan dasar dalam penyusunan perencanaan keperawatan, oleh karena itu diagnosa keperawatan ini harus terdokumentasi dengan baik.

Metode dokumentasi diagnosa keperawatan meliputi:

a. Tuliskan masalah/problem pasien atau perubahan status kesehatan pasien.

b. Masalah yang dialami pasien didahului adanya penyebab dan keduanya dihubungkan dengan kata "sehubungan dengan atau berhubungan dengan".

c. Setelah masalah (problem) dan penyebab (etiologi), kemudian diikuti dengan tanda dan gejala (symtom) yang dihubungkan dengan kata "ditandai dengan".

d. Tulis istilah atau kata-kata yang umum digunakan.

e. Gunakan bahasa yang tidak memvonis.

3. Perencanaan

Perencanaan merupakan pengembangan dari strategi untuk mencegah, mengurangi atau mengoreksi masalah-masalah yang diidentifikasi pada diagnosa keperawatan. Pada tahap ini perawat membuat rencana tindakan keperawatan untuk mengatasi masalah dan meningkatkan kesehatan pasien. Perencanaan keperawatan adalah suatu rangkaian kegiatan penentuan langkah-langkah pemecahan masalah dan prioritasnya, perumusan tujuan, rencana tindakan dan penilaian asuhan keperawatan pada pasien/klien berdasarkan analisis data dan diagnosa keperawatan.

Tujuan dokumentasi perencanaan keperawatan keperawatan adalah:

a. Untuk mengidentifikasi fokus keperawatan kepada klien atau kelompok 
b. Untuk membedakan tanggungjawab perawat dengan profesi kesehatan lainnya

c. Untuk menyediakan suatu kriteria guna pengulangan dan evaluasi Keperawatan

d. Untuk menyediakan kriteria klasifikasi klien

e. Menyediakan suatu pedoman dalam penulisan.

Karakteristik dalam pendokumentasian rencana tindakan keperawatan dapat terlihat

sebagai berikut:

a. Di tulis oleh perawat

Rencana tindakan dibuat oleh perawat dengan mempertimbangkan aspek profesionalisme sehingga rencana yang dibuat di dokumentasikan dengan baik dan benar

b. Dilaksanakan setelah kontak pertama kali dengan pasien

Segera setelah melakukan pengkajian, perawat seharusnya memulai untuk melakukan pendokumentasiannya diikuti dengan penentuan diagnosa keperawatan baik aktual atau risiko, tujuan, kriteria hasil, rencana tindakan.

c. Disimpan dalam tempat yang mudah untuk dijangkau

Dokumentasi yang telah dilakukan oleh perawat, hendaknya di simpan di tempat yang mudah dijangkau oleh perawat atau tim kesehatan lainnya.

d. Informasi yang ada harus diperbaharui

Semua komponen dalam rencana perawatan harus selalu diperbaharui. Tujuan, kriteria hasil dan rencana tindakan tidak valid harus diperbaiki.

4. Implementasi

Intervensi dan Implementasi Keperawatan menitikberatkan pada bagaimana proses perencanaan intervensi yang berisi aktivitas yang akan dilakukan perawat kepada pasien serta pencatatan tindakan yang telah dilakukan kepada pasien dan respon pasien terhadap tindakan yang diberikan.

Terdapat tiga kategori dari implementasi keperawatan, antara lain:

a. Cognitive Implementations, meliputi pengajaran/pendidikan, menghubungkan tingkat pengetahuan klien dengan kegiatan hidup sehari-hari, membuat strategi untuk klien dengan disfungsi komunikasi, memberikan umpan balik, mengawasi tim keperawatan, mengawasi penampilan klien dan keluarga, serta menciptakan lingkungan sesuai kebutuhan, dan lain lain.

b. Interpersonal Implementations, meliputi koordinasi kegiatan-kegiatan, meningkatkan pelayanan, menciptakan komunikasi terapeutik, menetapkan jadwal 
personal, pengungkapan perasaan, memberikan dukungan spiritual, bertindak sebagai advokasi klien, role model, dan lain lain.

c. Technical Implementations, meliputi pemberian perawatan kebersihan kulit, melakukan aktivitas rutin keperawatan, menemukan perubahan dari data dasar klien, mengorganisir respons klien yang abnormal, melakukan tindakan keperawatan mandiri, kolaborasi, dan rujukan, dan lain-lain.

5. Evaluasi

Dokumentasi pada tahap evaluasi adalah membandingkan secara sistematik dan terencana tentang kesehatan klien dengan tujuan yang telah ditetapkan dengan kenyataan yang ada pada klien, dilakukan dengan cara bersinambungan dengan melibatkan klien dan tenaga kesehatan lainnya. Evaluasi keperawatan merupakan tahap akhir dari rangkaian proses keperawatan yang berguna apakah tujuan dari tindakan keperawatan yang telah dilakukan tercapai atau perlu pendekatan lain.

Penilaian dalam keperawatan merupakan kegiatan dalam melaksanakan rencana tindakan yang telah ditentukan, untuk mengetahui pemenuhan kebutuhan klien secara optimal dan mengukur hasil dari proses keperawatan. Evaluasi keperawatan adalah mengukur keberhasilan dari rencana dan pelaksanaan tindakan keperawatan yang dilakukan dalam memenuhi kebutuhan klien. Penilaian adalah tahap yang menentukan apakah tujuan tercapai. Evaluasi selalu berkaitan dengan tujuan.

Evaluasi disusun menggunakan SOAP secara operasional dengan sumatif (dilakukan selama proses asuhan keperawatan) dan formatif (dengan proses dan evaluasi akhir). Evaluasi dapat dibagi menjadi 2 jenis yaitu:

a. Evaluasi berjalan (sumatif)

Evaluasi jenis ini dikerjakan dalam bentuk pengisian format catatan perkembangan dengan berorientasi kepada masalah yang dialami oleh keluarga. format yang dipakai adalah format SOAP.

b. Evaluasi akhir (formatif)

Evaluasi jenis ini dikerjakan dengan cara membandingkan antara tujuan yang akan dicapai. Bila terdapat kesenjangan diantara keduanya, mungkin semua tahap dalam proses keperawatan perlu ditinjau kembali, agar didapat data-data, masalah atau rencana yang perlu dimodifikasi.

\section{Penutup}


Asuhan keperawatan merupakan hal sangat penting bagi seorang perawat. Kemampuan memberikan pelayanan yang baik serta kemudian dapat secara efektif mengkomunikasikan tentang perawatan pasien tergantung pada seberapa baik kualitas informasi yang diberikan serta dokumentasi yang disediakan untuk dimanfaatkan oleh semua profesional kesehatan dan antar bidang pelayanan kesehatan.

Proses keperawatan adalah metode pemberian asuhan keperawatan yang dilakukan secara sistematis, teratur dan berkelanjutan untuk membantu klien/pasien mengatasi masalah keperawatan yang dihadapinya melalui serangkaian intervensi berdasarkan ilmu dan kiat keperawatan. Proses tersebut meliputi pengkajian, diagnosa keperawatan, perencanaan, tindakan dan evaluasi.

Pendokumentasian proses keperawatan sangatlah penting dalam menjaga kualitas dan kontinuitas pelayanan keperawatan. Pendokumentasian asuhan keperawatan yang tidak lengkap mengakibatkan mutu Rumah Sakit akan menurun. Untuk itu dokumentasi dalam setiap tahapan proses keperawatan yang terdiri dari pengkajian, penentuan diagnosa, intervensi, implementasi dan evaluasi perlu dipelajari dengan baik, agar pencatatan asuhan perawatan dapat terjamin.

\section{Daftar Pustaka}

Olfah, Y. 2016. Modul Bahan Ajar Cetak Keperawatan : Dokumentasi Keperawatan. Jakarta : Pusdik SDM Kesehatan

Rosmalia, D., Machmud, R., Mangkuto, H. 2014. Analisis Sistim Manajemen Dokumentasi Keperawatan pada Poliklinik Gigi Rumah Sakit di Bukittinggi. Jurnal Kesehatan Andalas, 3(1), 967-972

Wulandari, D. F., Handiyani, H. 2019. Pengembangan Dokumentasi Keperawatan Berbasis Elektronik Di RS X Kota Depok Dengan Menggunakan Teori Perubahan Lewins. Jurnal Keperawatan Global, 4 (1), 65-64

Rum, M. R. 2019. Faktor-Faktor yang mempengaruhi Kepatuhan Perawat dalam Pendokumentasian Asuhan Keperawatan. Jurnal Ilmiah Kesehatan, 18 (1), 4-9

Dewi, R., Maigeni. 2018. Lama Masa Kerja Dan Manajemen Waktu Dengan Pelaksanaan Dokumentasi Asuhan Keperawatan. REAL in Nursing Journal, 1 (1), 30-41 
Efnawati, S. D., Agustin, R., Husna, A. R. 2015. Analisis Faktor : Perilaku Pendokumentasian Asuhan Keperawatan Di RS PKU Muhammadiyah Surabaya. The Sun, 2 (4), 1-9

Koerniawan, D., Daeli, N. E., Srimayati. 2020. Aplikasi Standar Proses Keperawatan : Diagnosis, Outcome, Dan Intervensi Pada Asuhan Keperawatan. Jurnal Keperawatan Silampari, 3 (2), 739-751

Tarigan, R., Handiyani, H. 2019. Manfaat Implementasi Dokumentasi Asuhan Keperawatan Berbasis Komputerisasi Dalam Meningkatkan Mutu Asuhan Keperawatan. Jurnal Ilmiah Kesehatan Pencerah, 8 (2), 110-116

Muryani, Pertiwiwati, E., Setiawan, H. 2019. Kualitas Pendokumentasian Asuhan Keperawatan di Ruang Rawat Inap (Studi di RSUD Kalimantan Tengah). Nerspedia, 2 (1), 2732

Noviari, E. A., Susanti, D. D. 2015. Faktor-Faktor Yang Mempengaruhi Kelengkapan Dokumentasi Asuhan Keperawatan Di Ruang Bedah RSUD dr. Soekardjo Kota Tasikmalaya. Buletin Media Informasi, Edisi 1

Simamora, R. (2009). Dokumentasi Proses Keperawatan.

Simamora, R. H., Purba, J. M., Bukit, E. K., \& Nurbaiti, N. (2019). Penguatan Peran Perawat Dalam Pelaksanaan Asuhan Keperawatan Melalui Pelatihan Layanan Prima. JPPM (Jurnal Pengabdian Dan Pemberdayaan Masyarakat), 3(1), 25-31. 